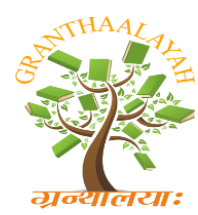

INTERNATIONAL JOURNAL OF RESEARCH GRANTHAALAYAH

A knowledge Repository

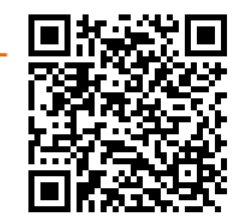

Social

\title{
NATIVE AMERICAN PERSPECTIVE IN LINDA HOGAN'S MEAN SPIRIT
}

\author{
M. Sathiya ${ }^{1}$, Dr. S. Ramya ${ }^{2}$ \\ ${ }^{1}$ Part-Time Research Scholar, K.N Govt.Arts College for Women (Autonomous), Thanjavur, \\ INDIA \\ ${ }^{2}$ Research Advisor, Assistant Professor of English, K.N Govt. Arts College for Women \\ (Autonomous), Thanjavur, INDIA
}

\begin{abstract}
This Paper focuses on the Native American's struggles and problems through their color and racial discrimination. Linda hogan, a native American and Ecofeminism, a renowned writer. Her novels fully based on the problems of Native Americans, particularly "Mean Spirit" she discussed in an elaborate way and Women also combined together nature and themselves with an effective way.
\end{abstract}

Keywords:

Native American's, racial discrimination, Mean Spirit.

Cite This Article: M. Sathiya, and Dr. S. Ramya, "NATIVE AMERICAN PERSPECTIVE IN LINDA HOGAN'S MEAN SPIRIT" International Journal of Research - Granthaalayah, Vol. 4, No. 1 (2016): 185-188.

\section{INTRODUCTION}

Linda Hogan is Chickasaw. Her father is a Chickasaw from a recognized historical family and Linda's uncle, Wesley Henderson, helped form the White Buffalo Board in Denver during the 1950s. It was to help other Indian people coming to the city because of The Relocation Act, which encouraged exodus for work and other opportunities. He had a strong influence on her and she grew up relating strongly to both her Chickasaw family in Indian Region (Oklahoma) and to a mixed Indian community in the Denver area. At other times, her family traveled because of the military. Hogan was a professor at the University of Colorado at Boulder and the University of Oklahoma. She is also a novelist and essayist. Her work centers on the world of native peoples, from both her own aboriginal perspective and that of others. She was a full professor of Creative Writing at the University of Colorado and then taught the last two years in the University's Ethnic Studies Department. Specifically, because of the environmental crises that produce skirmish in each novel, Linda Hogan, a poet, novelist, and environmental activist, is also a border-crosser. As Greta Gaard contends, "ecofeminist scholars will need to irritate the problem of cross-cultural ecofeminist ethics and develop a process for determining the applications and 
limitations of ecofeminist analyses across the boundaries of culture. Hogan's texts cross borders, not only between cultures, but between non-humans and humans. Removal and survival: Indian country in Hogan's hands is a physical and historical process articulated metaphorically and characterized by a seemingly infinite permanency across generations, crosshatched by discrete yet dangerously contagious episodes of cultural disruption. Incarnated in stories, Indian country and its inhabitants sometimes achieve a highly valued and spirited connectedness to each other, a rootedness. "Mean Spirit" is set in the 1920s. It interweaves fiction with fact and history concerning the oil murders of that time, a time when white men married Osage women - and then murdered them - to gain control of their oil leases. The background of the novel's action is provided by Lila Blanket and her daughter Grace. Repeating the warning the Blue River has "spoken" to her, Lila tells the other Hill Indians that white people are going to impose upon the tribe's peaceful ways; to prevent their own downfall, she says, they must send some of their children to town to learn the white ways. Lila sends Grace to live with her friends the Grayclouds, hoping she will grow up and protect the Hill people with her knowledge. Grace, however, takes little interest in the old Indian ways, acquires an allotment of land, and strikes the richest oil vein in the territory. Her discovery of oil in the territory does indeed save the Hill people, as the current building of a dam on the Blue River is discontinued. Yet the riches that come to the Indian public also destroy it. The beginning of the novel, Grace Blanket is murdered. Grace's thirteen-year-old daughter Nola and her friend Rena, hidden in the river mud, witness the brutal killing and watch as the unidentifiable murderers assemble Grace's body to suggest suicide. Because the killers are unaware of the witnesses, Belle and Moses Graycloud keep the children's knowledge secret in hope of protecting Nola, who, though she is constantly guarded by four mystical hill "runners," also brings a threat to the entire Graycloud family.

Throughout Mean Spirit, Hogan represents racialzed identity as a complicated give-and take, an economy of actions and reactions, preconceptions and reconstructions. With race as with various other issues, she brightens, critiques, and celebrates states of being in the dark. Hogan often calls attention to the physical, material nature of racialized identity by specifying not only skin colors but also the color of a character's hair and the style of his or her clothing. Cross-racing becomes fashionable: Creek girls at the Indian school grow spellbound with "white heaven," dye their hair yellow, and begin to wear white gowns. Meanwhile, one of the school's white matrons

"began dying her hair black, and asked if she could attend the peyote church" (171 M.S). Similarly, in "real" history, when Federal Bureau of Investigation agents began looking into the "Osage Reign of Terror," they found disguises necessary; as Kenny Franks notes, federal agents dressed up as "cowboys, insurance salesmen, and Indian traders" when in Oklahoma. Michael Horse, the character who is probably the most observant observer of his own people, even remarks that "She looks darker every day. Linda Hogan, a Chickasaw writer with a fine reputation as a poet, has chosen as the subject of her first novel the Oklahoma oil boom of the 1920s. The Indians who had been forcibly resettled onto apparently worthless land suddenly found themselves in possession of one of the country's richest oil fields--to their great misfortune. U.S. businessmen and government, as it happened, couldn't bear the sight of a rich Indian, and although the history of Native Americans since occupation is a fairly predictable story of betrayal and land theft, this chapter is a particular shocker. Only a poet could have made it both shocking and beautiful to read. 
The novel is set in Watona, where Osage and Creek families live in farmhouses above a great pool of oil, and one by one are turning up dead. An old water-diviner named Michael Horse watches his fire and tries to piece together the mystery But God seems to be elsewhere when oilmen arrive spontaneous to pump out the earth's black blood and pay the landowners as little as possible. When Moses Graycloud goes to collect the annual royalty payment that must support his family (since his land is ruined for farming), he's told that full-bloods now get only $10 \%$ : $\$ 200$. Any who argue are declared insane and employed the wards of white attorneys who handle their money. Some who can't pay their bills get a loan from the benevolent rancher and oilman John Hale, who secures the loan with a life-insurance policy on which he'll collect when they die. He never has to wait long.

At the eye of the storm is Nola Blanket, beautiful daughter of the murdered Grace Blanket, heir to her mother's enormous oil fortune but also precious progeny of the Hill People, who shun Watona's worldliness but send down four silent guardians to watch over Nola.

She embodies every conflict of her time. She saw one of John Hale's men shoot her mother, but if she reports this it surely will end her own life. She is a child scarred by horror, but also a gentle, unearthly beauty who inspires love and fear in her oppressors. She vividly defies her boarding-school teachers, but then agrees to marry the son of her court-appointed warden because she knows her presence in Moses and Belle Graycloud's home endangers them. She spends her money on a wildly opulent wedding and extravagant gifts for her people. When she becomes pregnant, she talks regularly to "her future," the only thing left for her to trust.

Nola's story is woven together with that of Belle Graycloud, who listens to bees and wears a meteorite around her neck; of Stacey Red Hawk, a smart Lakota Sioux who tucks his braids into his hat and goes to Washington in hopes that law enforcement can be made honest; of mute John Stink, who sneaks from his grave and walks the Earth more freely as a ghost than he could in life.

The tapestry is as well made as a good mystery novel, but equally compelling for its vivid language and characters. When Belle Graycloud happens on a truckload of sacred eagles "with the blue-white membranes of death closed over their eyes," shot by hunters who will sell them for remembrances, they look to her "like a tribe of small, gone people, murdered and taken away in the back of a truck." When Nola Blanket's husband gives her an emerald-green parrot, she walks like an apparition to the window and sets it free.

The stereotype of the stoic Indian who does not flinch as he's beaten was probably invented by a guilty conscience. The Indians in this novel aren't stoic. When they can, they laugh and make love; when they can't, they weep and lock themselves in the cellar. When their own traditions can't guide them or blunt their despair, they turn to liquor and Ouija boards. They aren't "other," they're ourselves.

Hogan has done one of the finest things a novelist can do: She's created empathy. She carves a vast tragedy down to a size and shape that will fit into a human heart. It's an central event, because this chance to fully gather a point of view alien to our own--this empathy--is the thing that may just save us in the end. 


\section{REFERENCES}

[1] Adamson, Joni. American Indian Literature, Environmental Justice, and Ecocriticism: The Middle Place. Tucson: U of Arizona P, 2001.

[2] Baird, W. David. The Osage People. Ed. John I. Griffin. Phoenix: Indian Tribal Series, 1972.

[3] Hogan, Linda. Dwellings: A Spiritual History of the Living World. New York: Touchstone, 1995.

[4] Mean Spirit. New York: Ivy, 1990.

[5] Power. New York: W.W. Norton, 1998.

[6] Walter, Eugene Victor. Placeways: A Theory of the Human Environment. Chapel Hill: $U$ of North Carolina P, 1988 